Para enlazar con este artículo / To link to this article:

https://doi.org/10.6035/MonTI.2020.12.13

Para citar este artículo / To cite this article:

Romero Fresco, Pablo. (2020) "The accessible filmmaker and the global film." In: Richart-Marset, Mabel \& Francesca Calamita (eds.) 2020. Traducción y Accesibilidad en los medios de comunicación: de la teoría a la práctica / Translation and Media Accessibility: from Theory to Practice. MonTI 12, pp. 381-417.

\title{
THE ACCESSIBLE FILMMAKER AND THE GLOBAL FILM
}

\author{
PABLO ROMERO-FRESCO \\ promero@uvigo.es \\ p.romero-fresco@roehampton.ac.uk \\ University of Vigo
}

\begin{abstract}
As well as an alternative approach to audiovisual translation and media accessibility, accessible filmmaking (AFM), the integration of translation and accessibility into the filmmaking process through the collaboration of filmmakers and translators, is a new approach to filmmaking. The aim of this article is to ascertain what filmmakers need (in theory and practice) to become accessible filmmakers. Firstly, the reason for the gap between film and translation/media accessibility is explored and a new translation-oriented notion of film studies is presented. A new concept (the global film) is then introduced to help filmmakers widen their perspective beyond the original version of their films. Examples are provided of pioneering filmmakers who have already considered the global film and applied a similar approach to the AFM model. Finally, the article looks at how the concept of the global film and the AFM model were applied to the feature-length documentary Where Memory Ends.
\end{abstract}

Keywords: Accessible filmmaker; Accessible filmmaking; Audiovisual translation; Global film; Media accessibility.

\section{Resumen}

Además de un enfoque alternativo al modelo actual de traducción audiovisual y accesibilidad a los medios, la producción audiovisual accesible es una nueva forma de hacer cine. El objetivo de este artículo es determinar qué precisan los cineastas 
para ser cineastas accesibles. En primer lugar, se exploran los motivos que explican la separación actual entre el cine y la traducción/accesibilidad y se propone una visión de los estudios de cine que considere la traducción. Se introduce un nuevo concepto (la película global) para contribuir a que los cineastas amplíen su perspectiva más allá de la versión original de sus películas. Se proporcionan ejemplos de cineastas pioneros que pusieron en práctica modelos similares al de producción audiovisual accesible. Por último, se reflexiona sobre cómo el concepto de película global y el modelo de producción audiovisual accesible se aplicaron al documental Donde se acaba la memoria.

Palabras clave: cineasta accesible; producción audiovisual accesible; traducción audiovisual; película global; accesibilidad a los medios.

\section{Introduction}

Although audiovisual translation and media accessibility are still considerably neglected in the film industry, the new trends of audiovisual consumption in our society and the pervasiveness of on-demand platforms such as HBO, Amazon prime or Netflix are bringing the issue of language transfer to the fore. In January 2019, newspapers such as The New York Times, The Guardian, and El País reported extensively on Netflix's controversial decision to offer Iberian Spanish subtitles for Alfonso Cuarón's critically-acclaimed film Roma (Jones 2019, Marshall 2019, Morales 2019). The discussion turned the spotlight on an area that is as essential in the film industry as it is invisible. The controversy revolved around whether or not translating Mexican Spanish into Iberian Spanish is redundant, patronising, or even a sign of colonial superiority. However, Cuarón's surprise and anger when finding out about this shows another aspect that was largely overlooked, which may be even more important: how is it possible that a filmmaker like Cuarón, who was on top of every aspect of this labour of love, including fulfilling the role of director of photography, was never aware of this decision?

In a news piece published on $25^{\text {th }}$ April 2019 (Billson 2019), a journalist from The Guardian explained that subtitlers are "pressing film-makers for more appreciation of their art", since "too many filmmakers look on subtitling as an afterthought". A subtitler interviewed for the piece summed up the problem as follows: 
A film-maker wouldn't outsource their colour correction or audio mix and just think: 'I'll leave them to it, I'm sure it'll be fine.' They would want to see it, hear it, get a second opinion, make sure everybody is on the same page. It should be the same with subtitles.

In order to offer both a theoretical framework and a practical model to tackle this issue, accessible filmmaking (AFM) aims to consider translation and/ or accessibility during the production of audiovisual media (through the collaboration between the creative team and the translator) in order to provide access to content for people who cannot access or who have difficulty accessing it in its original form (Romero-Fresco 2019a: 5-6). It is worth noting here that accessible filmmaking adheres to a wide notion of media accessibility (Romero-Fresco 2018) that is no longer exclusively focused on persons with sensory disabilities, but "concerns access to media products, services, and environments for all persons who cannot, or cannot completely, access them in their original form" (Greco 2016: 23). Accessible filmmaking is thus concerned with both traditional media accessibility modalities such as subtitles for the deaf and hard of hearing and audio description but also with audiovisual translation modalities such as interlingual subtitling and dubbing, which will be the focus of most of the examples mentioned in this article.

Research on AFM has so far focused, amongst many other aspects, on positioning AFM within the new and wider area of accessibility studies (Greco 2018), comparing the idea of access to content with that of access to creation (Dangerfield 2018), analysing the workflow required in the application of this model (Romero-Fresco \& Fryer 2018), presenting the new professional figure of the director of accessibility and translation (Branson 2019), exploring the use of creative subtitles (Varela 2018), etc. Although a lot of this work has been done from the perspective of audiovisual translation and media accessibility, if a solid collaboration is to be built with creative teams it is essential to turn our attention to the filmmakers. This is the aim of the present article, which attempts to answer the following question: what do filmmakers need (in theory and practice) to become accessible filmmakers?

The following section explores the reason for the gap between film and translation/media accessibility and suggests a new translation-oriented notion of film studies. Section 3 introduces a new concept (the global film) that may be useful for filmmakers to widen their perspective and consider more than 
just the original version of their films. This is divided into subsections devoted to similar concepts used in different contexts, examples in which the notion of global film could have helped to solve translational issues and, finally, an account of pioneering filmmakers who have already considered the global film and applied a similar approach to the AFM model, albeit inadvertently and inconsistently. Section 4 focuses on the practical side, that is, how the concept of the global film and the AFM model was applied to the feature-length documentary Where Memory Ends (Romero-Fresco 2019b). A final section concludes the article and points towards the next steps required to adopt an integrated and collaborative approach to film and translation/media access.

\section{The relation between film and translation/accessibility}

As mentioned above, in over a century of very prolific and interdisciplinary work, film studies has largely failed to engage with translation and accessibility both thoroughly and consistently. The aim of this section is to explore the reasons for this and to put forward a new translation- and accessibility-oriented notion of film studies that can be operationalised in filmmaking practice through the notion of AFM.

\subsection{The invisibility of translation and accessibility within film studies}

The few film scholars who have engaged with translation often start by expressing their surprise at the little attention paid to this topic despite it being the main means of access to foreign cinema (Flynn 2016: 1) and playing a fundamental role in mediating the foreign (Nornes 2007: 4). As noted by Dwyer (Longo 2017), film has been surrounded by translation since its very origin, and not only for geographical reasons. Fiction films involve the translation of words on a script into on-screen images whereas, to name but one example, ethnographic documentaries may require a triple case of translation (Barbash 1997), rendering aspects of one culture intelligible to another, transforming cultural elements into the film medium and transferring meaning from one language into another. At least three different explanations may be considered as to why the practicalities and risks posed by translation have been largely ignored in film. Firstly, despite the film-as-language metaphor often used in this area (Nornes 2007: 18), Dwyer (Longo 2017) notes that 
there is still a "primacy of the visual", which may be linked to an ocularcentric view of film and a "misguided notion of film as Esperanto". In other words, this is the (questionable) belief that what really matters in film is the image, since it is what made film a universal language in the silent era, before the introduction of sound.

Secondly, another reason accounting for the invisibility of translation within film studies is precisely translation's long-standing vocation for invisibility; in other words, the traditional notion that the translation of a film is good when it goes unnoticed. Nornes (2007: 155) criticises the cultural appropriation involved in what he considers a corrupt and colonial approach that "domesticates all otherness while it pretends to bring the audience to an experience of the foreign". As an alternative to this "corrupt subtitling" that separates spectators from "the beauty of the original" (2007: 19), Nornes (1999: 32) introduces the notion of "abusive subtitling". Nornes' stance is very useful to denounce the cultural and political implications of "invisible" approaches to translation and to highlight the creative potential of subtitles. However, the aim of AFM is to increase the visibility of translation in film studies and in the film industry by making it part of film discourse and the production process, respectively. Whether or not actual translations are more or less domesticating or foreignising (or corrupt or abusive) will be determined by the newly established collaboration between filmmakers and translators. At any rate, there is little doubt that the invisibility of translation (and accessibility) within film studies is a reflection of the place it occupies in the industry as an afterthought or necessary evil (Serban 2012: 49) that is "added post-filmically and without aesthetic intention" (Flynn 2016: 22). In this industrialised model, translators are "relegated to a sub-species below the tea assistant within the filmmaking hierarchy" (Fozooni 2006: 194) and, as is the case with football referees, they are normally never praised, and only noticed when an error occurs. As pointed out by Crow (2005), this results in translation and media accessibility being shoe-horned into existing templates that bear no relation to the film, which may undermine not only its aesthetics but also the vision that the filmmaker has worked so hard to create and communicate. This makes the absence of literature on translation within film studies more glaring and the few contributions available (discussed in the next subsection) all the more compelling. 
Finally, and most importantly for the purpose of this article, a third reason for the invisibility of translation within film studies may be found in the apparatus theory. A dominant school of thought within cinema studies during the 1970s, this theory was based on the denial of difference (Baudry $\&$ Williams 1974), which is precisely what translation provides to film. Foreign audiences may have a very different experience to that of the original audience or even to that of foreign audiences from other countries depending on whether a film is shown with different types of subtitles, dubbed or with a voice-over narration. Eleftheriotis (2010: 187) notes, for example, that subtitles must have been an integral part of the filmic experience of the French theorists who analysed this apparatus so thoroughly. Yet, they never acknowledged (let alone analyse) the presence of subtitles, which would have posed a threat to the perceived objectivity and universality of their claims. For Eleftheriotis (2010: 187), this has two implications:

The first is a logical extension of the apparatus theory rationale and suggests that films operate by constructing universal positions that transcend difference, in other words, that the cinematic apparatus and its effects are universal and immune to national/cultural variations. The second is the apparatus theorists' inability to acknowledge the specificity of their own position as one of necessarily partial and limited understanding rather than perfect mastery over the 'foreign' text. Ultimately, such a position resides in the realm of a politically suspect fantasy and typifies modern sensibilities (...) that value the possibility and desirability of universal knowledge that transcends national and cultural specificity. It is profoundly elitist as it elevates the theorist to a level of immense cultural and epistemological power.

This article, and AFM in general, go in the opposite direction. The intention is to tackle head on (and even embrace) the difference brought about by translation, which includes a) acknowledging the difference between original and translated/accessible film versions, b) identifying the effect it may have on the viewers' experience, c) promoting a notion of film studies that can account for this difference in the analysis of film and especially d) introducing a new collaborative filmmaking model that can consider translation early in the process in an attempt to bridge the gap between the experience of the different audiences. 


\subsection{A new translation-oriented notion of film studies}

Those film scholars who have discussed translation and accessibility have often done so from the perspective of world, slow, transnational, ethnographic or multilingual cinema. Eleftheriotis (2010: 179) describes world cinema as a "discursive space occupied de facto by foreigners, foreign films and foreign spectators", whose encounters are made possible by dubbing or by subtitles, which are "the most widely shared characteristic of world cinema". The same goes for slow cinema, a type of cinema that "takes its time" through "static camerawork, minimal editing and scarce or slow movement within the frame" (Dwyer, Tessa \& Perkins 2018: 103). Slow cinema normally targets foreign-language audiences, so subtitles are de rigueur (Dwyer, Tessa \& Perkins 2018). As for transnational, ethnographic and multilingual cinema, they share the peculiarity that there is often no unsubtitled version of the film, as the original audience needs access to the foreign language(s) included in the original version of the film. Here, subtitles are often a deliberate artistic choice by the filmmaker, as long as the producers agree to include several languages in the original version.

Three main common points may be gleaned from the contributions by film scholars discussing translation, and more specifically subtitling, in film: subtitles are integral to the film (and to its analysis), they must be analysed beyond their linguistic dimension and they trigger a different viewing experience to that of the viewers of the original version. The notion of subtitles as an integral component of film calls for serious reconsideration of how translated cinema has been analysed in film studies to date. Subtitles advance the plot and thus fulfil a narrative role. They contribute to further the characterisation of the participants in the film and help filmmakers to recontextualise, focus or narrow down their ideas. Subtitles are a 'stamp of possession' (MacDougall 1998: 174), the 'textual eyes' (Zhang 2012: 447) that allow filmmakers to project their particular interpretation and to speak to the audience while the participants in the film are speaking to each other. In light of this, film scholars have embraced a cultural rather than linguistic approach to translation. Egoyan and Balfour (2004: 25) note that subtitles trigger questions of "otherness, representation, national identities and the tasks of cultural interpretation", whereas Eleftheriotis (2010: 179) views them as cultural imprints or a "visual testimony (like visa stamps on a passport)" 
of the film's journey. The focus is no longer placed on subtitles as signifiers of linguistic meaning or as external elements that come "from the outside to make sense of the inside" (Sinha 2004: 173), but on the "affective force of subtitled film viewing" (Flynn 2016: 5) and on the role of subtitles as "affective bodily expressions" (Flynn 2016: 16) that have the potential to transform filmic experiences.

The latter is a particularly recurrent point made by film scholars looking at subtitles, some of whom suggest that the dramatic impact that subtitles have on the viewers' film experience (Bergfelder 2005) may warrant the consideration of the foreign spectator as a "theoretically productive conceptual category" (Eleftheriotis 2010: 179). From a perceptual viewpoint, Shochat $\&$ Stam (1985: 41) note that the experience of the foreign viewer watching a subtitled film is bifurcated as they hear a foreign language and read their own, while trying not to miss the images and forge a synthetic unity that can help them make sense of the film. As a result of this process, subtitles impact on the rhythm of film or, at the very least, on the rhythm at which film is viewed. This has been noted by MacDougall (1998), Eisenschitz (2013) and Cuarón (Aguilar 2019), based on the films they have made or translated; and by Dwyer and Perkins (2018), based on recent eye-tracking research. In their analysis of viewers' eye movements watching slow cinema, Dwyer and Perkins (2018: 123) found that the visual momentum (the rhythm at which the film is viewed) is increased by the presence of subtitles, which trigger a more visually intense experience, promote active and critical engagement and "are central to the affective experience that filmmakers intend all along". The perceptual and affective dimensions are thus combined, as subtitles "set us on a course for an affective encounter that is distinct from the original, untranslated film experience" (Flynn 2016: 12). For Eleftheriotis (2010: 185) foreign spectators are required to oscillate "between the narrative depth of the film and its surface where the subtitles reside", undertaking "complex and often unpredictable negotiations between what is familiar and what is strange". This line of thought enables Eleftheriotis (2010: 188) to put forward a consideration of subtitling (and, by extension, film translation), which may be regarded as the theoretical, film studies equivalent of the AFM notion presented in this article: 
An embracement of incompleteness, imperfection, limits and limitations, but not of impossibility in the encounter between spectators and 'foreign' texts. This position is marked by awareness of one's own relation to the foreign text/culture and of the limitations and imperfect understandings that it entails. It is also characterised by an active reading both of the subtitles and of the formal codes of the film and by a constant oscillation between familiar and strange that cuts across the domestic/foreign binary. It is a form of engagement that accepts gaps and lacunae in the experience while at the same time strives to overcome cultural and linguistic barriers by a semiotic reading of the filmic text alongside the literal reading of the subtitles. A cross-cultural critical practice that corresponds to such model would be one of modest and limited claims, acute awareness of the position from which the critic analyses and speaks, openness to the possibility of errors and misunderstandings, painstaking attention to textual and contextual detail but also a determination in the pursuit and acknowledgement of the value of such partial knowledge.

Just as AFM requires filmmakers to consider from inception (and in collaboration with translators) the impact that translation and accessibility may have on the nature and reception of their films, it also requires film scholars, film analysts and film reviewers to acknowledge the specificities involved in watching the foreign version of a film as opposed to the original version. Yet, in order to acknowledge these specificities, it may also be necessary to refer to a global version (Romero-Fresco 2019a) or global film, the one that encompasses the original and its translated and accessible versions.

\section{The global film}

How does the risk of translation affect the medium? How does it affect its global address? How does translation as risk, as failure, as dysfunction allow us to reconceive the global currency and globalizing nature of screen media? This risk involves mismatch, error, cultural asymmetries, appropriation, censorship, gatekeeping, etc. It also involves renewal and revitalization, activity, mobility, activation, accessibility. Cinema and screen media are situated within and amongst these forces and flows-which need to be acknowledged and unpacked (Longo 2017).

\subsection{Background and related terms}

The origins of the notion of the global film may be found in theories addressing the heterogeneity, fluidity or multiplicity of literary texts, such as Jerome 
McGann's idea of the textual condition (1991). McGann focuses on the instability of the physical text, and more specifically the literary text, as it undergoes a ceaseless process of textual development and mutation performed by authors, editors, typographers, book designers, marketing planners, and other publishing agents. However, the most pertinent reference applied to audiovisual texts is the notion of le film pluriel, which is also the name of a research group founded in 2006 by Michel Marie and François Thomas at Université Sorbonne Nouvelle - Paris 3. Le film pluriel refers to the many different and co-existing versions of a film, which make up a whole that helps question the identity of a film from its production to its reception by the audience throughout its many different lives (Thomas 2006). According to Marie and Thomas, the idea that there is a single and unique original version that may be used as an object of study is no longer tenable. The study of this plural film leads these authors to question what film we are really watching, what film is being the basis for scholarly analysis and who the author is. It acknowledges the limitations involved in the analysis of only one version of a film, thus being in line with Eleftheriotis' advice (2010) to be aware of one's own relation to, and partial knowledge about, the film. Like AFM, le film pluriel does not deny the difference between different versions of the same film, but rather embraces them as a necessary prerequisite for its analysis. However, with a few exceptions, these authors seem mostly concerned with different versions of the original film, rather than with the translated or accessible versions, which are never mentioned (Thomas 2006):

Films muets tournés à plusieurs caméras (d'où des négatifs différents selon les pays de diffusion), versions muettes coexistant avec les versions parlantes pour les salles non équipées pour le son à la fin des années 20, versions multiples des débuts du parlant, remontages soviétiques remaniant l'idéologie des films, versions censurées, versions d'exportation écourtées ou allongées, repentirs tardifs des metteurs en scène, versions feuilleton télévisé coexistant avec une version cinéma, versions en relief et versions « plates»...et des dizaines d'autres.

Even when adopting an angle that may be seen as particularly conducive to the study of what happens when films are translated or made accessible, film studies seems to overlook the role played by translation and accessibility in the production and analysis of films. Drawing on the notion of le film pluriel and highlighting the geographical aspect involved in translation, AFM resorts 
to the concept of the global version (Romero-Fresco 2019: 22) or perhaps more accurately the global film, to refer to the original and the translated and accessible versions of a film. The following two sections (3.2 and 3.3) include, respectively, a case that considers the need for this global film and an account of those (accessible) filmmakers who have already factored it in their practice.

\subsection{The case for the global film}

In the classic book Hitchcock (Truffaut 1966), recently adapted into a feature-length documentary (Jones 2015) and widely regarded as one of the most influential books on film studies ever published, Truffaut and Hitchcock discuss at length many of Hitchcock's films. They cover every aspect involved in filmmaking, from planning and scriptwriting to shooting, acting, editing and even the reception of the films. Everything except for translation (or access). There is not one single mention of translation or the foreign audience. For all the readers know, both filmmakers seem to have watched, and be referring to, the same version of the films. We know that Truffaut, who conducts the interview in French with a liaison interpreter in order to communicate with Hitchcock, watched the French version with subtitles, but there is no acknowledgment of potential "gaps and lacunae in the experience" by Truffaut or signs of "acute awareness of the position" from which he analyses the films as he "strives to overcome cultural and linguistic barriers" (Eleftheriotis 2010: 185). If, as explained in decades of research in audiovisual translation and media accessibility, translation (and more specifically subtitling) has such a dramatic impact on the viewers' experience that it can change the rhythm at which the film is watched and trigger a different affective response to the original version, to what extent can both filmmakers discuss the films (including aspects of rhythm and editing) as if they had watched the same version? Furthermore, the trailer of the film (Jones 2015) highlights the following quote by Hitchcock:

There is sometimes a tendency among filmmakers to forget the audience.

(...) I am interested in the audience. Obviously, they are going to sit there and say "Show me. I know what's coming next". I have to say: "Do you?".

As well as summing up Hitchcock's approach to filmmaking, these words show how the filmmaker falls prey to the same tendency that he is denouncing. As 
mentioned above, he never once mentioned the translation of his films, which means that he is forgetting the (very large) audience of these foreign versions. In other words, both Truffaut (in this case as a critic) and Hitchcock (as a filmmaker) are denying the difference between original translated versions. Truffaut watches a translation and pretends he has access to the original, whereas Hitchcock appears to be talking about the whole of the audience but is actually only referring to the original viewers. None of them seems to bear in mind the global film.

Far from a merely theoretical or terminological consideration, the notion of the global film and the distinction between its different versions are often necessary for the analysis of film. Take for example Mogambo (Ford 1953), which is included in the Eddie Mannix Ledger as a worldwide success in the history of cinema. When Monaco (1992) praises the subtle script about a love triangle involving the white safari leader Victor Marswell (played by Clark Gable), the showgirl Eloise Kelly (played by Ava Gardner) and the cool and married Linda Nordley (played by Grace Kelly) or when he recalls Ford's words about why he made the film ("I liked the script and the story (...) - so I just did it"), he is referring to the original film, albeit the underlying idea is that this normally applies to foreign versions of the film too. However, the Spanish dubbed version was very different. In order to eliminate adultery, the Francoist censors changed the relationship of the characters played by Grace Kelly and Donald Sinden from wife and husband to sister and brother. This required the removal of a bedroom scene in which only one bed is present and which, as noted by Galán (1981), replaced adultery with incest. The heavily modified Spanish version is far from the subtle script praised by Monaco and from the story about adultery that persuaded Ford to make the film in the first place. When talking about this film, it thus becomes necessary to specify which version is being referred to. Monaco and Ford's words apply only to the original version; Galán's, to the Spanish dubbed version; and the Eddie Mannix Ledger's description of Mogambo as a worldwide success is referring to the global film, that is, the one that encompasses the original version and all or some of its translated/accessible versions.

A more modern example of the need to consider the global film is that of Munich (Spielberg 2005), which tells the story of the terrorist attack orchestrated by the Palestinian group Black September to kill several members of 
the Israeli Olympic team at the 1972 Munich Olympics and especially of the secret retaliation organised by the Israeli government. Spielberg, himself a Jew, was very aware that the focus would be placed on his political stance and whether the film may be seen as "condoning or condemning Israel's action" (Morris 2007: 360). In this sense, one of the key lines of the film, included in the trailer, is said by Israeli Prime Minister Golda Meir, who justifies the retaliation by saying that "every civilization finds it necessary to negotiate compromises with its own values". In the Spanish dubbed version, she says "cada civilización se ve obligada a llegar a un compromiso con sus propios valores" ("every civilization finds it necessary to commit to its own values"). In other words, whereas in the original version, Meir says that Israel is not a violent country, but it may have to be this time round, the Spanish version may be interpreted as though Israel is to retaliate because it is a violent country. This example illustrates once again the need for analysts to make a distinction between original and translated versions but also the need for filmmakers to supervise the global film, thus ensuring a degree of consistency across translated and accessible versions. The AFM model aims to make this possible by promoting and articulating the collaboration between filmmakers and translators. And while it may be difficult for a filmmaker to have complete control/knowledge of every aspect of every translated version, it is reasonable to expect them to supervise the content regarding a line as important as this one, which is a key part of the film, of the trailer and of Spielberg's stance on the political conflict between Israel and Palestine.

This need to distinguish between original, translated and global versions is not only justified by, and does not only apply to, cases of mistranslation. As mentioned above, films with subtitles are often viewed so differently that in some aspects they may sometimes become a different film altogether. The case of dubbing, where all actors' voices are replaced by those of new actors in a different language, is even clearer. There Will Be Blood (Thomas Anderson 2007) was highly praised for its direction, cinematography, editing and, especially, acting, with Daniel Day Lewis winning an Oscar, a Bafta, a Golden Globe and many other accolades. Much of the praise towards his acting was focused on his speech, which was allegedly modelled on actor-director John Huston's voice and which for several dialect experts is an uncanny reproduction of vintage, early American Californian accent, built around the oral 
posture, "with his tongue stuck in the middle of his mouth, bracing against the molars, leaving his cheeks loose" (Singer 2016). This is very different from the vocal work involved in his also revered performance as William Cutting in Gangs of New York (Scorsese 2002), where, according to Singer (2016), he mirrors $19^{\text {th }}$-century New York accent to perfection by having the tip of his tongue hit his teeth while producing a colourful tone with a great deal of nasality. In Spain, There Will Be Blood was met with very positive reviews but Daniel Day Lewis' performance divided critics. In El Pais, Spanish critic Carlos Boyero (2007) showed his surprise at the praise he received for his performance, which, for him, is too similar to his role as William Cutting in Gangs of New York. In the Spanish versions of these films, Daniel Day Lewis is dubbed by the Catalan dubbing actor Jordi Brau, who uses the same voice and accent for both films. While this is understandable, given the very little preparation time available for dubbing actors, it begs the question of to what extent a Spanish reviewer can rate an original performance based on a dubbed film.

An extreme case is that of non-visible performances, such as the supporting characters in Buried (Cortés 2010), a film set entirely inside a coffin. Only the main character is seen, alive inside his coffin, while the others are heard through the phone. The millions of viewers who watched the dubbed version in Spain, France, Italy or Germany did not have any access whatsoever to the key performances of Samantha Mathis as the main character's wife or that of Robert Paterson as Dan Brenner, a colleague trying to rescue the protagonist. Instead, in the case of Spain, they heard the voices of Victòria Pagès and Jordi Boixaderas, the dubbing actors. When Jordi Costa (2010), film critic for Fotogramas, praises their performance for the way they articulate their characters, is he referring to Samantha Mathis and Robert Paterson or to Victòria Pagès and Jordi Boixaderas? His remark can certainly not apply to all four and neither Victòria Pagès nor Jordi Boixaderas are mentioned in the review. It thus seems that he is praising Samantha Mathis' and Robert Paterson' performances, which is only possible if he has seen the subtitled version, not the dubbed one.

At the very least, reviewers should specify whether they are referring to the subtitled or the dubbed version. If the intention of the Spanish critics is to assess the performances by Daniel Day Lewis, Samantha Mathis or Robert 
Paterson, for instance, to consider whether they are worthy of an Academy Award, then it would make sense to watch either the original or the subtitled versions. If the critics only have access to the dubbed version, comments on the quality of the acting should refer both to Daniel Day Lewis' visual performance and Jordi Grau's vocal performance in the case of There Will Be Blood and Gangs of New York and only to Victòria Pagès and Jordi Boixaderas in the case of Buried. In a way, assessing foreign performances based on dubbed films is no less questionable than rating the performance of a lead singer in a musical where their voice is pre-recorded (and here at least it would be their own voice, and not that of another singer). Finally, if a reference is made on a website such as IMDb to the global versions of There Will Be Blood, Gangs of New York or Buried, highlighting for example the awards received by their original and translated versions worldwide, information about their cast should also include the dubbing professionals working in the different language versions. After all, they make up for at least $50 \%$ of the acting in the film (or almost $100 \%$ in the case of Buried and most animation films) as received by millions of viewers.

As shown by the above examples, there seems to be a widespread neglect and denial of translation. Filmmakers and film scholars, who control and/or analyse respectively every aspect of a film, tend not to consider how the nature and reception of films may be impacted upon by translation, just as foreign scholars and reviewers deny translation by pretending that they are accessing the original version even if they are not. In Eleftheriotis's words (2010: 183), this is "an act of violence, a powerful, imperialistic closing-down of possibilities that ignores the extensive transnational life of filmic texts". And, it could be argued, it is one that has contributed to silence differences, heterogeneity, manipulations through censorship and the work of many people (translators and more specifically dubbing artists) without whom cinema would not be able to travel.

However, there are exceptions, as some filmmakers have made a point of distinguishing between the original and translated versions of their films, looking after the former and after the coherence of what is called here the global film. They are the precursors of the accessible filmmaker addressed in the title of this article. 


\subsection{The precursors}

Filmmakers often become involved and interested in translation after experiencing poor quality issues, which prompts them to start considering the integrity of the global film. According to Oscar-winner director Guillermo del Toro, "a bad translation or an awkward rhythm in the subtitles can destroy dialogue and any sense of mood" (Murphy 2007). Del Toro learnt this lesson following the American release of his 2001 supernatural historical drama The Devil's Backbone (2001), whose subtitles, which he never reviewed, were criticised for being "awkward and cold" (Murphy 2007). For his next film, Pan's Labyrinth (del Toro 2006), he produced the English subtitles himself in collaboration with his writing partner, Mathew Robbins.

Indeed, the realisation of the impact that subtitles can have on the reception of a film often leads filmmakers to take it upon themselves to produce them or at least oversee them, as is the case for Hannes Stöhr's One Day in Europe (2005), Fatih Akin's The Edge of Heaven (2007) and Álvaro Gago's award-winning short film Matria (2017). The same goes for Alejandro Gonzalez Iñárritu's Babel (2006), for which the Mexican director "handed over a complete English script and went over the [Spanish] translation himself to make sure it was up to his standards" (Murphy 2007). An interesting case is that of Quentin Tarantino's Second World War drama Inglourious Basterds (2009), which features 70\% of the dialogue in French and German. Tarantino made it a priority to preserve the multilingual nature of the film in both the original and the translated versions. For the foreign versions, Tarantino included in the original script specifications as to whether subtitles should be incorporated and involved translators from Deluxe Digital Studios at the post-production stage to "oversee, transcribe and translate all of the footage" during the editing process (Sanz Ortega 2015: 157).

Other renowned filmmakers who have demanded to be involved in, or to keep some degree of control of, the foreign versions of their films are Federico Fellini, Martin Scorsese, Woody Allen, Jean-Luc Godard, and Stanley Kubrick (Nornes 2007). The last two are particularly interesting for the purpose of this article. In Le mépris (Godard 1963), which is set in the multilingual atmosphere of international co-productions, Godard fictionalises translation through the character of Francesca, an on-screen interpreter. Many scholars 
see this device as Godard's attempt to make his film impossible to dub (Lev 1993: 86), given his dislike for this translation modality. However, co-producer Carlo Ponti had the film dubbed in Italian against Godard's wishes, which led the French filmmaker to disown the film and remove his name from this version (Dwyer 2017). It could be argued that Godard did have in mind the notion of a global film and fought actively to preserve its coherence, to the extent that he was ready to disown one of the versions and not take responsibility for it when he considered that this coherence was lost.

As for Kubrick, he presents the most significant case of thorough and consistent integration of translation into the production process in classic Hollywood filmmaking, as he seemed to devise his own AFM model for dubbing and subtitling based on close collaboration with the translation team. This allowed him "to remain in control of the filmic text and to ensure that his vision was adequately represented in translation" (Zanotti 2018: 2). Thanks to recent archival research by Zanotti (2018), we now have first-hand evidence of Kubrick's approach to translation, often through personal correspondence. Kubrick used assistant editors or personal assistants to help him supervise the translators' work (LoBrutto 1997), a rough equivalent of the director of accessibility and translation proposed in the AFM model (Romero-Fresco 2019a). He phoned translators to discuss their approach before they started translating and provided them with annotations, not only to warn them about potential pitfalls, but also to guide their translation, be it for dubbing or subtitling. Again, this is not dissimilar to the meetings and the accessibility and translation guide envisaged within the AFM approach. Kubrick's letter to Jack Weiner on 3 January 1964 provides telling evidence of his approach to translation, the reasons behind it and how close it was to what we understand today as AFM; in his case, a particularly authorial approach to AFM. Interestingly, when he talks about "the film" ("I consider the translation and dubbing of the film an intrinsic part of the artistic side of the production of the film") he seems to be referring to the global film, thus encompassing both the original version and the subtitled/dubbed versions:

Dear Jack,

Regarding your cable on December 26th, 1963, I consider the translation and dubbing of the film an intrinsic part of the artistic side of the production of the film. While I am quite sure your people are the most able in the country, 
I am nevertheless the director and writer of the film and absolutely do not accept the principle that I must accept anyone else's opinion in regard to artistic matters over my own. My request to have a copy of the dubbing script for Germany, France and Italy in sufficient time to check them and make whatever revisions I think required is reasonable and consistent with the principle of my artistic control spelled out in my deal with Columbia. (Typescript SK/11/9/120 retrieved from the Stanley Kubrick Archive by Zanotti 2018b)

In Zanotti's view (2018: 1), Kubrick's example is an unorthodox practice within the film industry, "offering an alternative model in which film translation is integrated within the creative process of filmmaking through the film director's active participation in the translation process". Albeit inadvertently, Kubrick seems to be following many of the steps involved in AFM. He is certainly not the norm in the film industry, but his approach to translation is not dissimilar to that of many other filmmakers who are engaging with translation because a) they are making multilingual films involving translation in the original version, b) they are in need of creative approaches to translation and/or c) they are simply aware of the impact that translation can have on their film. This shows that, despite being unorthodox in the current industrialised translation and accessibility landscape, the AFM model is largely based on common sense and is made up of the logical steps that would be followed by any filmmaker who decides to consider not only the original but also the translated and accessible versions of their films, and thus the global film. However, it also highlights the importance of adopting a more systematic approach to the implementation of AFM, in order to ensure that the efforts to consider translation/accessibility are not wasted and that the filmmakers' original vision is truly maintained when it reaches foreign and sensory-impaired viewers.

The next section describes how this model and the notion of the global film have been applied to the feature-length documentary Where Memory Ends (Romero-Fresco 2019b).

\section{AFM in Where Memory Ends}

Donde se acaba la memoria (Where Memory Ends) is a feature-length documentary in which I have been working as a director and director of accessibility and translation for the past four years. As shown in the opening lines 
of the film, it tells the story of the famous Irish historian Ian Gibson and his indefatigable search to recover the historical memory of Spain through the biographies of some of its best known artists in the $20^{\text {th }}$ century:

In 1933, Luis Buñuel travelled to Las Hurdes to make a documentary about the Spain of the time. 80 years later, the historian Ian Gibson, biographer of Lorca, Dalí and Buñuel, made the same journey to complete the work of a lifetime.

In so far as it has been possible, I have tried to work on this film as an accessible filmmaker, considering the coherence of the global film (that is, the consistency between the original and the translated and accessible versions) and integrating translation and accessibility from the pre-production stage. This section includes a very brief analysis of how the AFM model has been applied at the different stages of the production of this documentary.

\subsection{Pre-production}

Although different issues regarding translation and accessibility often crop up at the pre-production stage, they are normally addressed by non-professional translators or ad hoc linguist experts who are not involved in the subsequent translation of the film. Adopting an AFM approach at this stage may help identify the impact translation/access can have on the film before production and how to make a more efficient use of translators by involving them throughout the process while providing them with the information they require to do their job.

Considering that in this case the director and the director of accessibility and translation were the same person, all the steps included in the AFM workflow for the pre-production stage (Romero-Fresco, 2019a) were followed: translation in the scriptwriting process, translation of script for funding, use of pre-production material to prepare the translation, initial meeting to consider the translational approach of the film and recruitment of MA professionals, translators and consultants with sensory impairments. In this case, the professionals recruited to translate the script for funding were the same ones who were entrusted with the translation of the film. An interesting aspect that was raised at this pre-production stage is that, given that the protagonist, Ian Gibson, is bilingual and that he was supposed to interview 
and interact with both Spanish- and English-speaking people, the original film would need to use subtitles (see figures 1-4). As will be explained below, this is an important consideration for the preparation of the shooting (story boarding, etc.) and for the future distribution of the film.
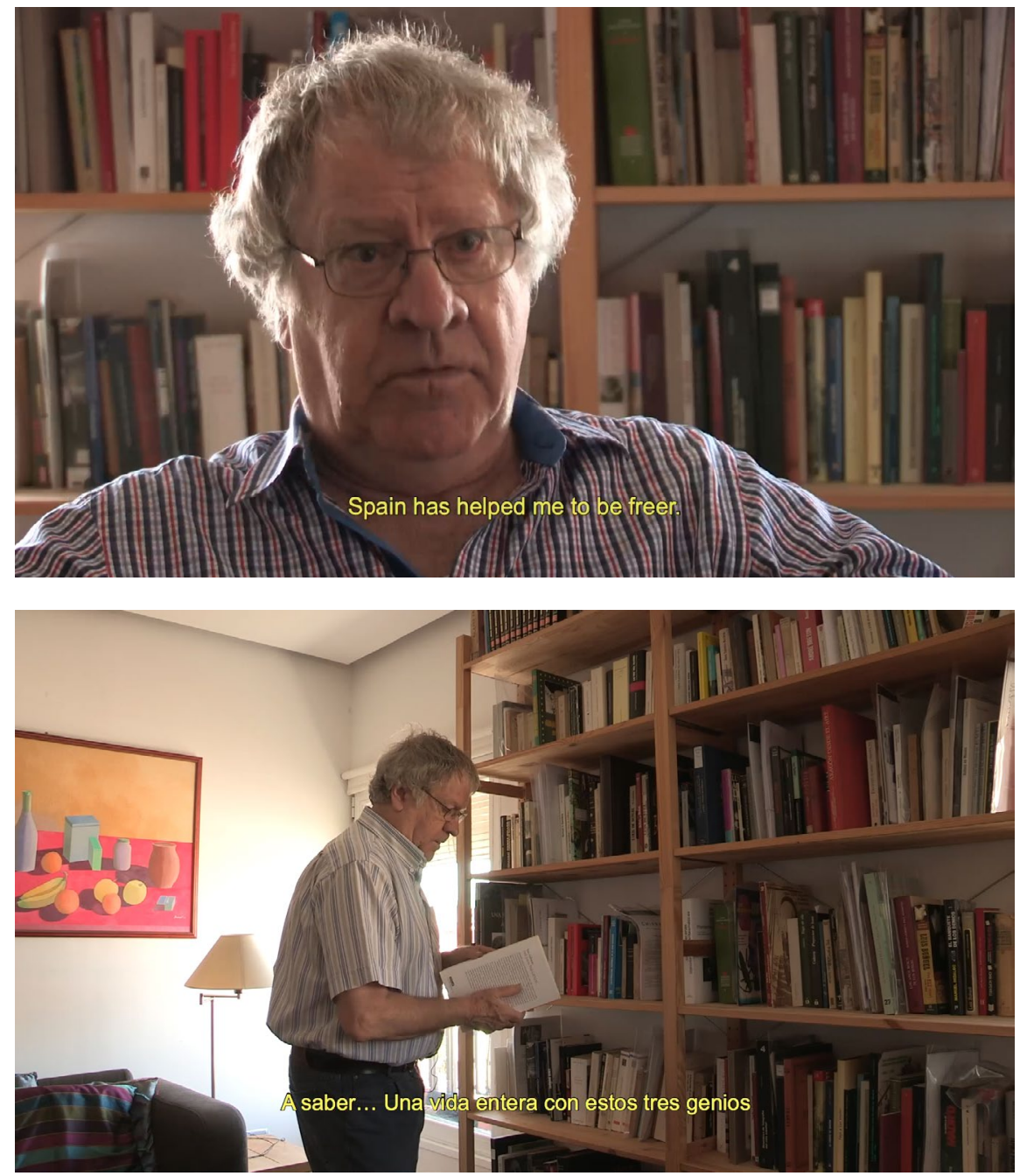

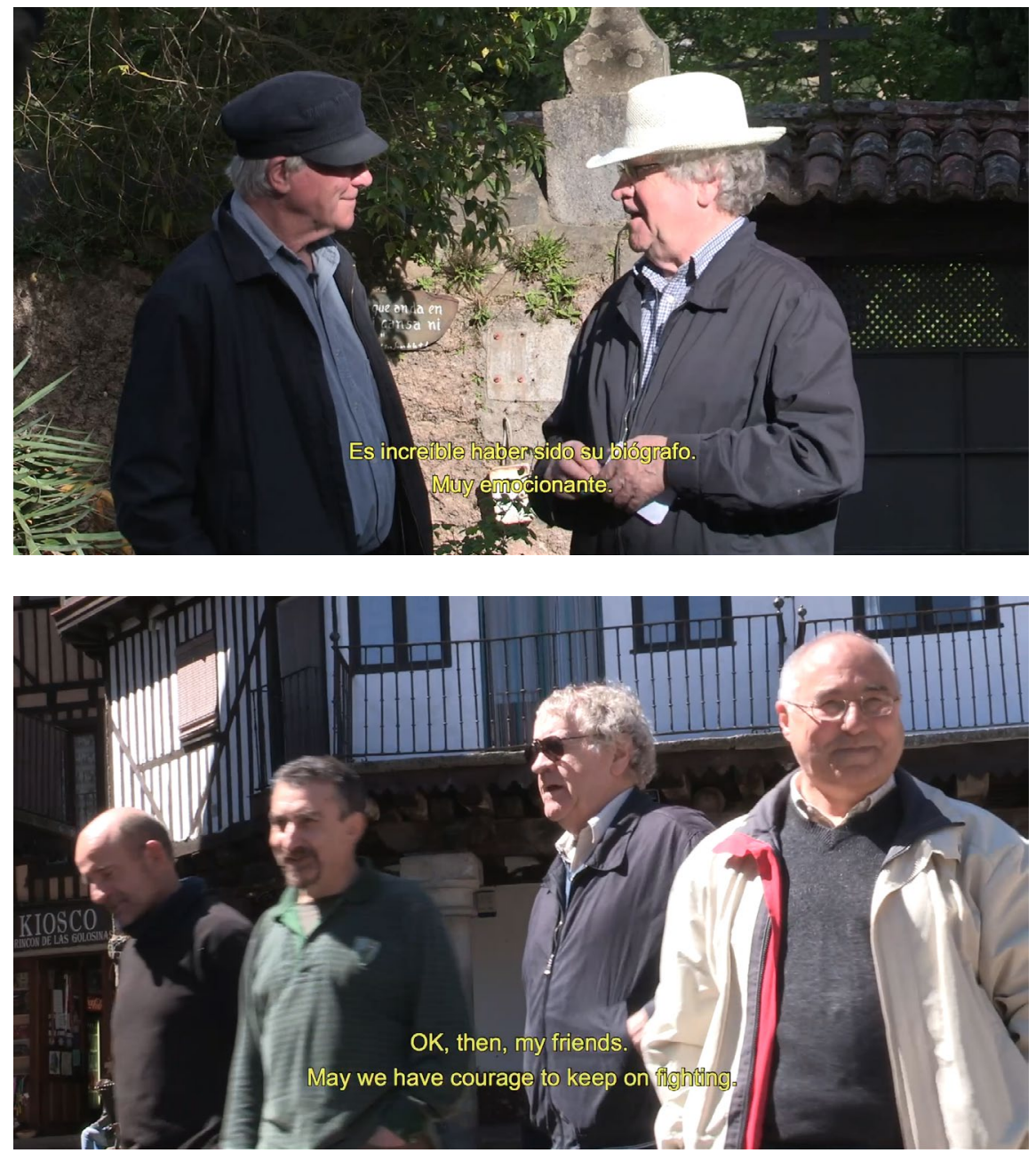

Figures 1-4: Spanish and English subtitles for Where Memory Ends

The fact that equal attention was paid from the beginning to the Spanish and English versions of the film begs the question of what the original version really is: is it the one with English subtitles, the one with Spanish subtitles or perhaps the unsubtitled version of the film, which sits in the editing software 
but will not be screened in public? As will be explained below, the application of the AFM model may often contribute to blurring the boundaries between the original and the translated/accessible versions of a film.

\subsection{Production}

Translation and accessibility can also play a significant role at the production phase, for instance by facilitating the communication amongst crew members who speak different languages and considering the impact that the mise en scène and cinematography may have on the reception of the film by foreign and sensory-impaired audiences. At this stage, when the relevant decisions regarding the mise en scène and cinematography are being made, there is still certain flexibility to address issues that can help ensure that the filmmaker's vision is maintained in the translated and accessible versions of the film.

In the shooting of Where Memory Ends, on-site translation (or rather interpreting) was needed, first of all, for communication between the participants and the non-Spanish-speaking members of the crew: Martina Trepzcyk, director of photography, and David Rhumer, sound recordist, both Austrian. Interestingly, as shown in Figure 5, I had to provide live simultaneous

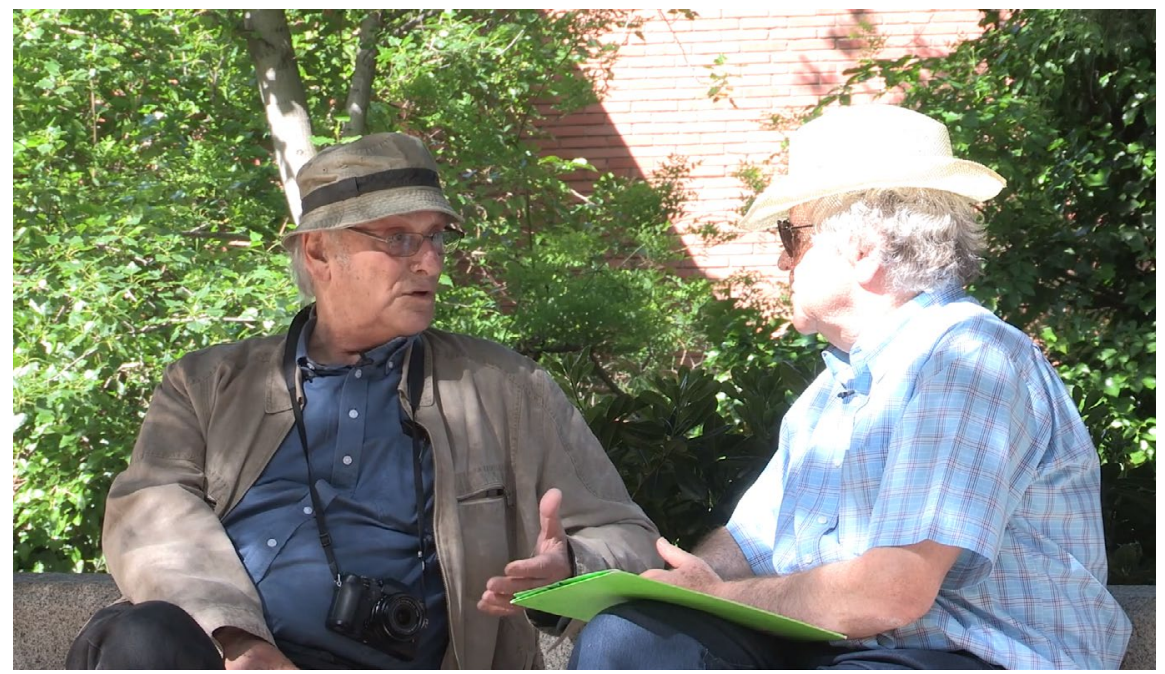

Figure 5. On-set simultaneous interpreting 
interpreting (chuchotage) for Martina during some of the interviews in Spanish, so that she could choose and adapt her framing depending on what was being said and how it was being said:

Translation and accessibility can also be very important during the production stage due to the organisation of space in the frame, which includes the mise en scène (what is seen) and the cinematography of the productions (how it is seen). Given that there is no unsubtitled version of Where Memory Ends, special consideration was given to cinematography and particularly to shot sizes and how subtitles were positioned on screen. As shown in Figure 6, while Martina was taking long and medium shots, a second cameraman, Mike Dibb, was taking close up shots from the left-hand side. A director of more than 70 films for the BBC and winner of a Bafta award for Ways of Seeing (1972) and an Emmy award for The Miles Davis Story (2001), Mike Dibb was used to filming tight close ups (see Figure 7). Whereas this is fine for a film with no subtitles, the viewers of the subtitled version (in the case of Where Memory Ends, all viewers) will be presented with a cluttered shot with the subtitle covering the mouth of the speaker, which, for some hard-of-hearing viewers, is essential to understand the dialogue through lip reading. It is for

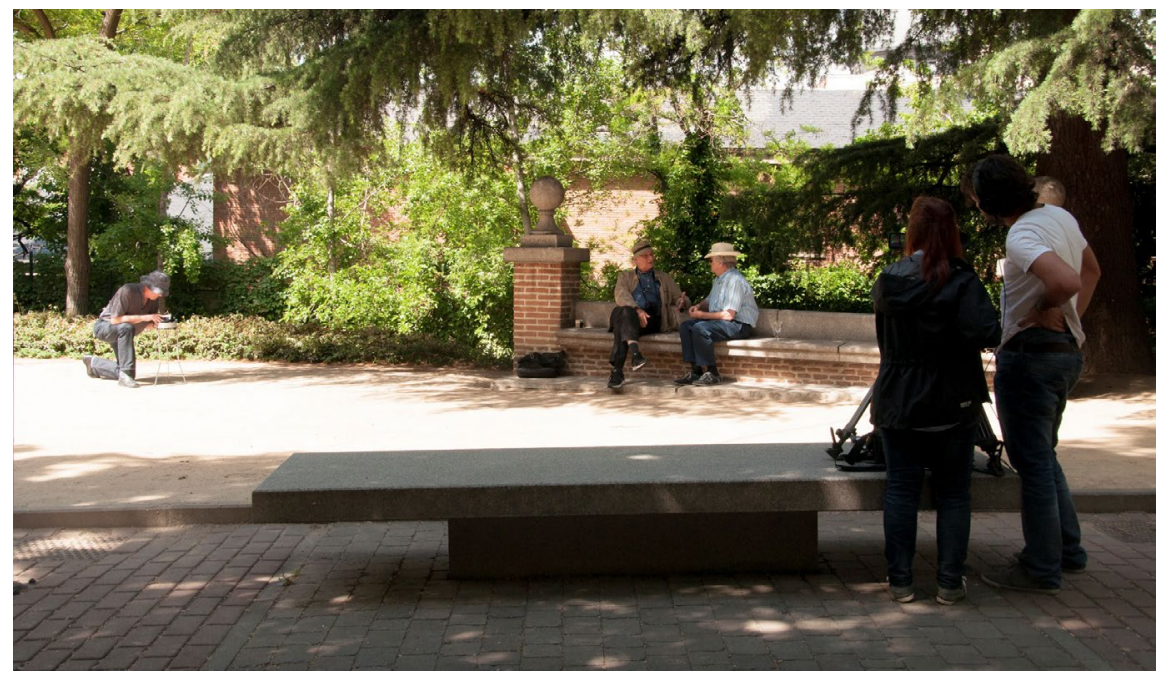

Figure 6: Two-camera set up for the shooting of Where Memory Ends 


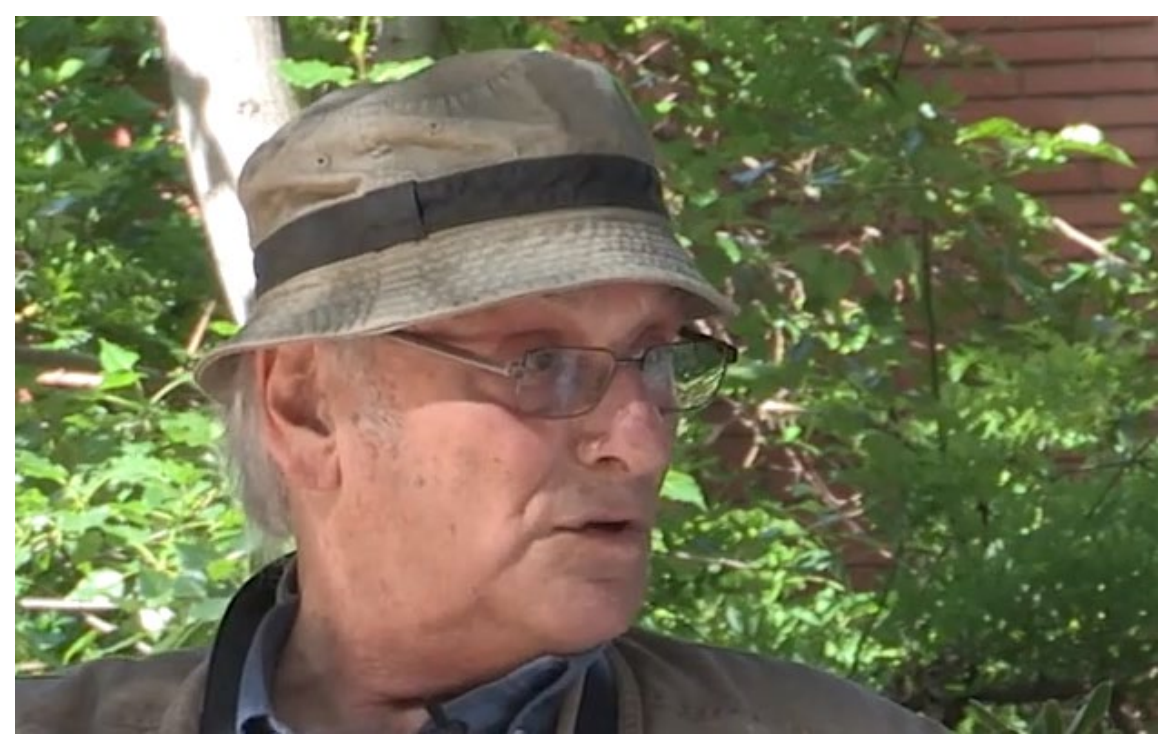

Figure 7. Tight close up of Carlos Saura

this reason that Mike decided to open up his close ups and allow space for the subtitles under the participant's mouth (see Figure 8). As mentioned in the introduction, AFM is just as much a new approach to translation and accessibility as it is a new way to make films.

Another important consideration regarding cinematography in the production stage is to leave space not only for the subtitles but also for the caption with the name and position of the participants the first time they are interviewed. In Figure 9, the framing of Ian Gibson at home allows for the subtitle to be placed at the bottom and for the caption to be positioned right over his shoulder, on the right-hand side of the frame, against the background of his book shelf.

\subsection{Post-production}

As has been mentioned, whereas in most films both translation and accessibility are considered during the distribution process (i.e. when the film has already been edited), taking them into account during the post-production 


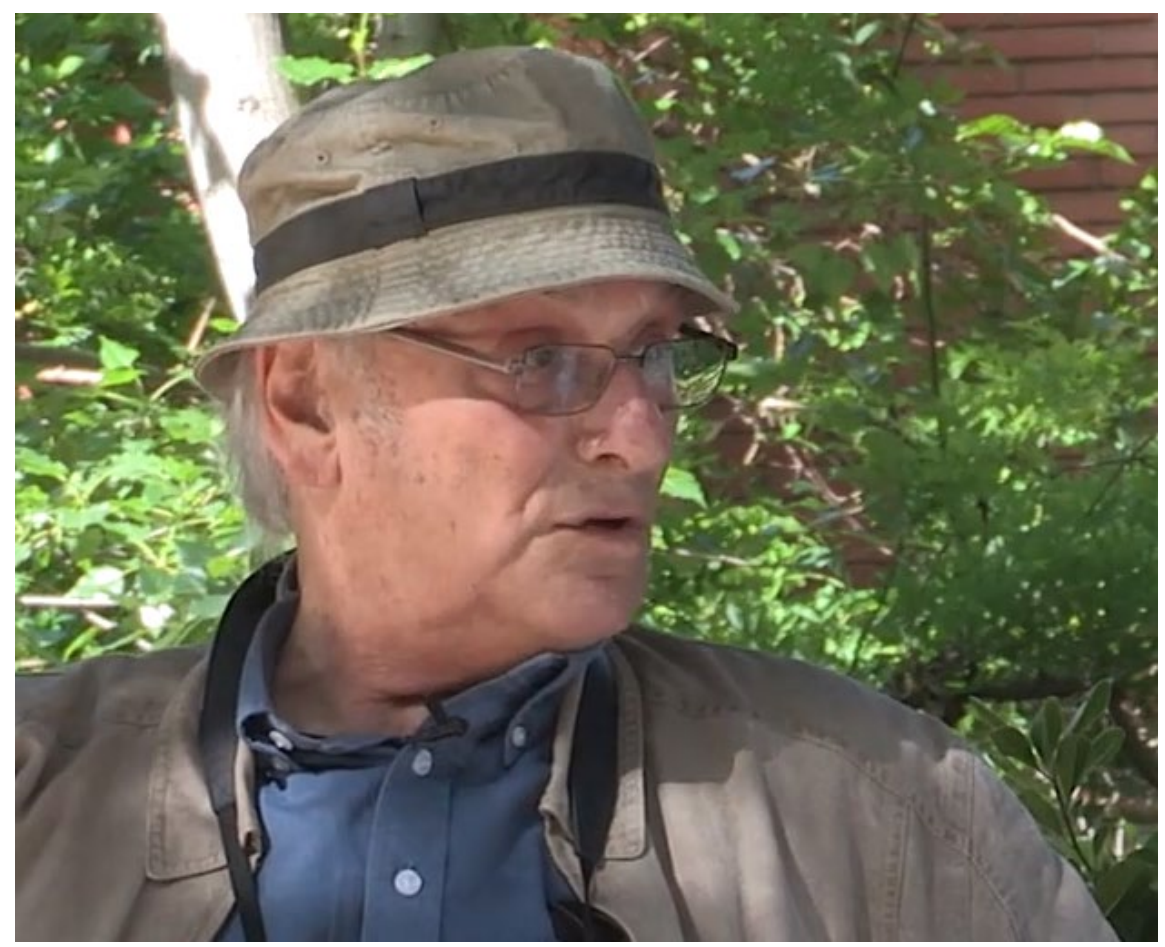

Figure 8. Accessible close up of Carlos Saura

stage can help solve some of the issues that widen the gap between the experience of the original viewers and that of those who watch the translated or accessible film.

Drawing on the AFM book and guide (Romero-Fresco \& Fryer 2018, Romero-Fresco 2019a), the main considerations in the production of subtitles for Where Memory Ends were the impact that subtitling could have on the content of the film and on the reception of the film by the viewers. The impact of subtitling on the film's content refers to linguistic aspects that have been studied at length in the literature of audiovisual translation, such as the use of subtitlese, language variation, multilingualism, the use of songs, etc. More interesting for the purpose of this article is the effect that the presence of subtitles on screen may have on the reception of the film by 


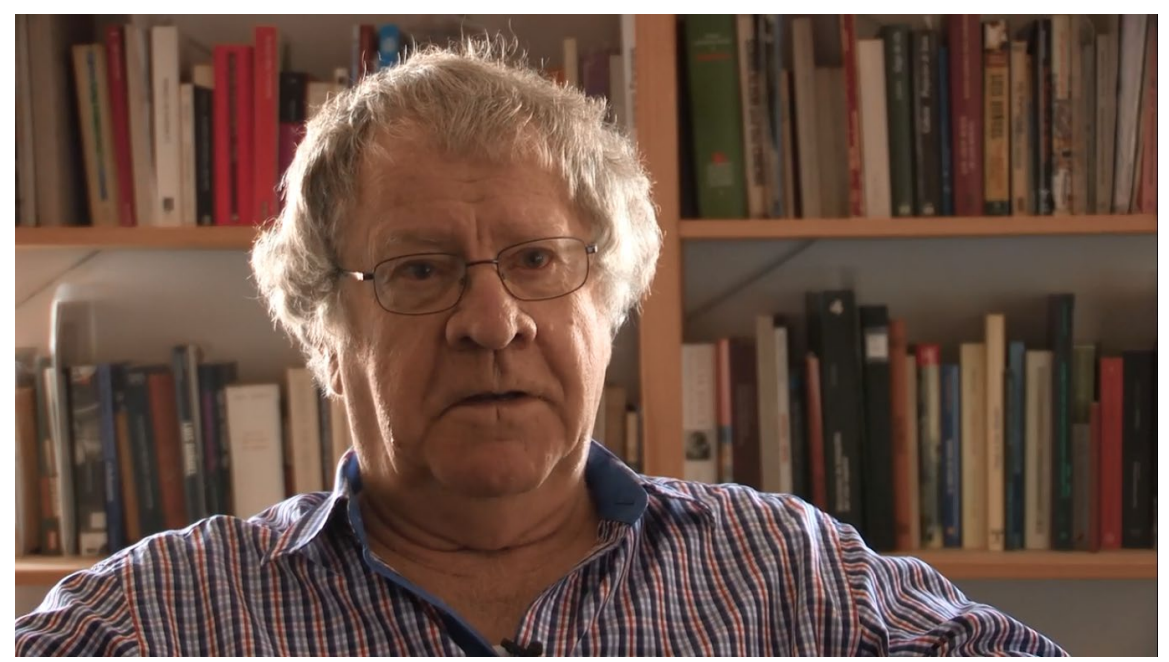

Figure 9. Accessible framing for Ian Gibson's interview

the viewers and more specifically the three issues that proved key in the case of Where Memory Ends: subtitling legibility, visual momentum and subtitling blindness (Romero-Fresco 2019a). Subtitling legibility is one of the most recurrent issues with subtitles. It is as easy to solve as easily forgotten, and it can have a fundamental impact on the viewers' experience. This is normally related to the mise en scène of a film but it is included here because it can be tackled in post-production. In the case of Where Memory Ends, the black and white archive footage from the Residencia de Estudiantes where Lorca, Dalí and Buñuel studied together do not provide enough contrast for the use of standard white subtitles (see Figure 10). The use of yellow subtitles or of a black outline around white subtitles is thus needed to ensure proper legibility.

As for visual momentum and subtitling blindness, they are key concepts to consider when applying the AFM model. As mentioned above, the visual momentum is the pace at which visual information is acquired (Hochberg and Brooks 1978). The introduction of subtitles in a film changes this pace as well as the overall viewing patterns of the audience. Up until now, filmmakers have focused on editing and on other elements such as the blocking of the actors or the music to manipulate and explore the sense of pace in film. Yet, 


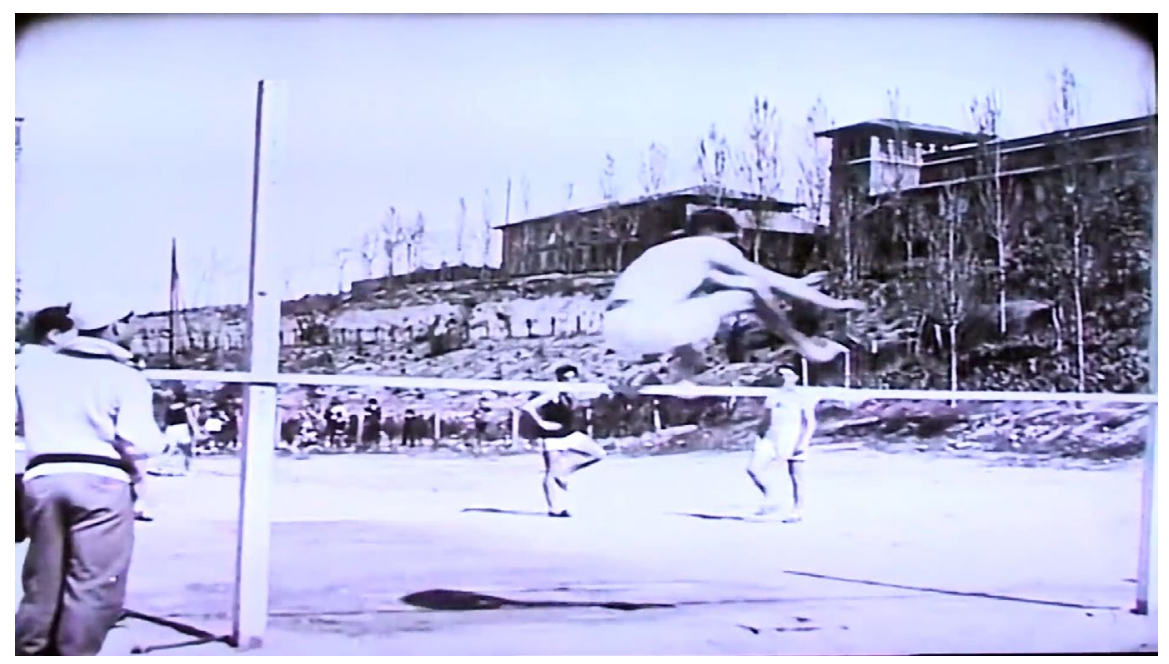

Figure 10. Archival footage from La Residencia de Estudiantes

in the case of subtitled films (or original films and series that use on-screen titles), the sense of pace is also determined by the speed at which subtitles are displayed and read by the viewers, which has so far been largely ignored by filmmakers and by the film industry as a whole. In the case of Where Memory Ends, special attention was paid to cases of subtitling blindness, that is, instances in which reading a subtitle could prevent viewers from watching an important part of the image on screen.

In Figure 11, the interviewee, Cheli Durán, is reading out a letter written by filmmaker Luis Buñuel to her father, Gustavo Durán, while the viewers see a medium shot of Cheli and a close up of the letter (see Figure 12). In the first edit of the film, the close up of the letter was shown along with the sound of Cheli reading it and talking about it. This had to be changed, as it meant that subtitles translating both the letter and Cheli's explanation about it had to be displayed over the close up of the letter. The result was a textheavy subtitled shot that was likely to increase the visual momentum and tempo for the viewers, which was aesthetically very different from what we had in mind originally and made it difficult for the viewers to see the image. 


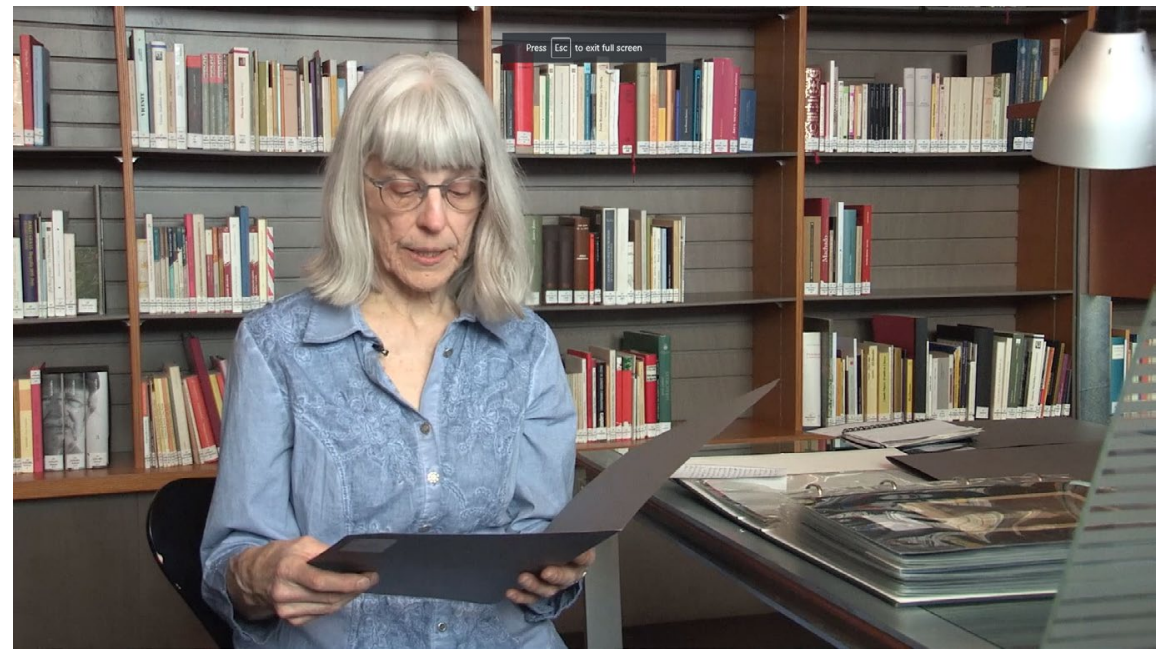

Figure 11. Cheli Durán’s interview

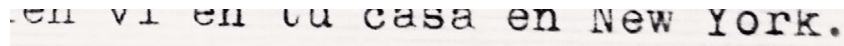
le se restableció completa-

: tu antiquisimo ami்go

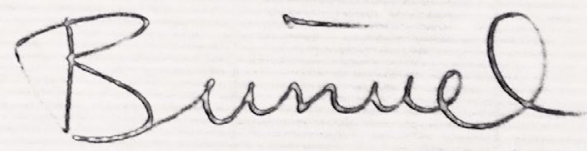

Figure 12. Close up of Luis Buñuel's letter to Gustavo Durán

In the final edit, Cheli's explanation was moved elsewhere, over a different shot, and the translation of the letter on the close up was provided with 


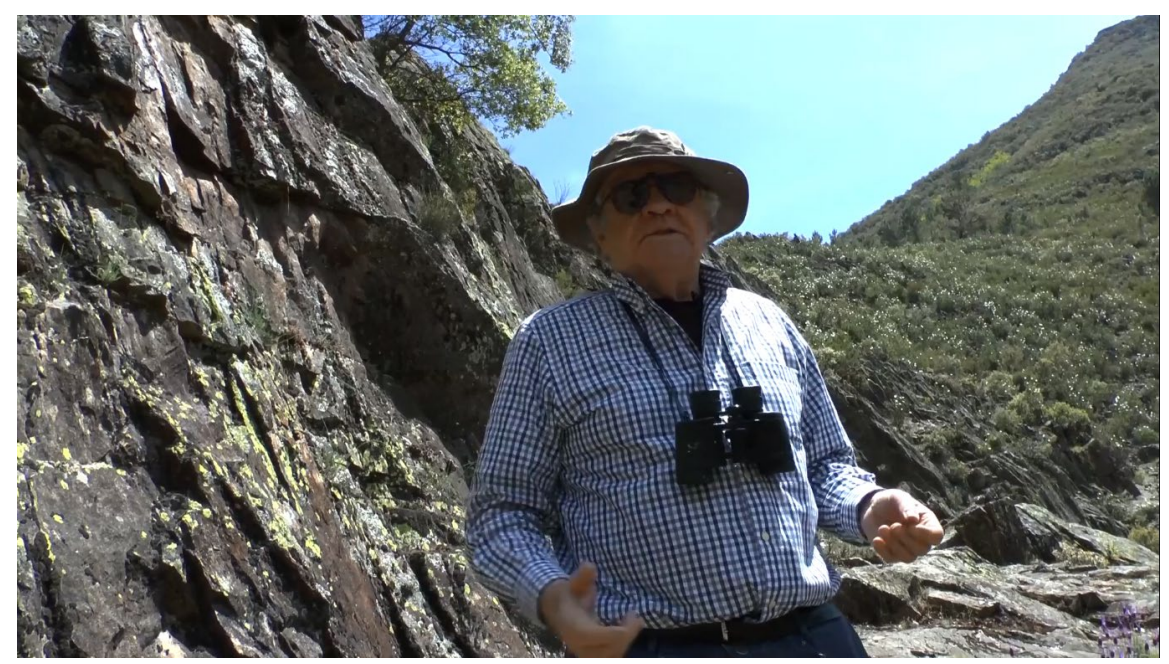

Figure 13. Ian Gibson at the bottom of the cliff

creative subtitles, with a similar font to the one used in the original letter and the words displayed one by one as the letter is being read by Cheli.

Finally, subtitling blindness was a key consideration in one of the most important scenes of the film, where Ian Gibson and Mike Dibb find the cliff that was shown in an iconic scene from Luis Buñuel's documentary Land without Bread. We first see them at the bottom of the cliff (see Figure 13), as they ponder (in English) whether it may be too dangerous to climb to the top.

The question is answered in the next shot (see Figure 14), which shows them as two tiny figures on the upper left-hand side of the screen, reaching the top of the cliff.

Initial test screenings for English-speaking audiences showed that the shot was on screen for just long enough so they could scan the image and locate Ian and Mike on top of the cliff, which often led to laughter. This was not the case, however, for the Spanish-speaking audience, who had to read the subtitle translating Ian and Mike's conversation and did not have enough time left to find them on the shot (see Figure 15).

This is a clear case of subtitling blindness that shows that unless subtitling is integrated into the filmmaking process (in this case, at the post-production 


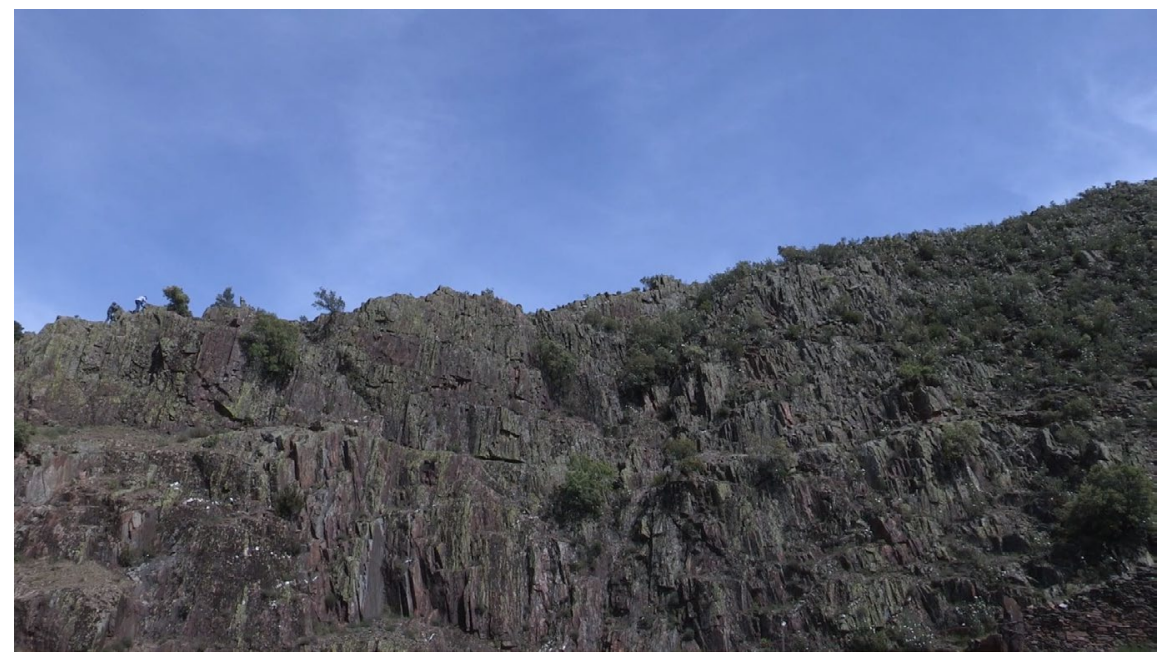

Figure 14. Ian Gibson and Mike Dibb at the top of the cliff (no subtitles)

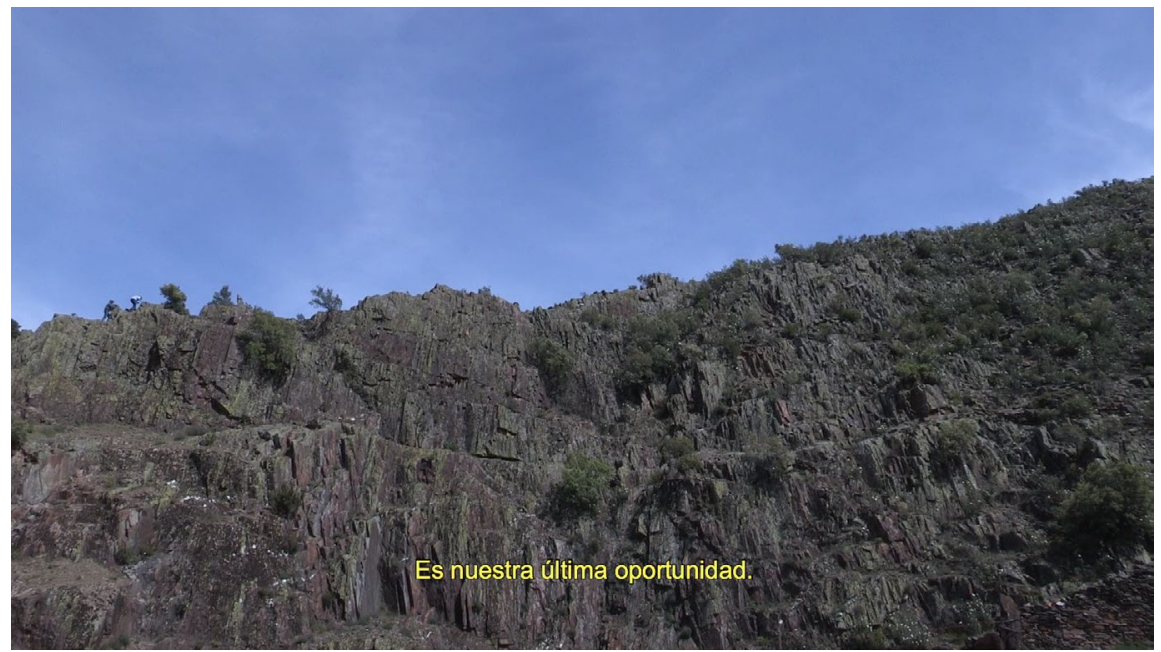

Figure 15. Ian Gibson and Mike Dibb at the top of the cliff (Spanish subtitles)

stage), the foreign (and deaf) viewers may end up watching a different film to those watching the original version, or, at least, they may watch the same 
film so differently that it becomes a different film. In an attempt to preserve the coherence of the global film and provide all viewers with an equivalent experience, the shot was extended for three seconds, which allowed the subtitling viewers to locate the two protagonists on the screen.

\section{Final thoughts}

As well as an alternative model to tackle audiovisual translation and media accessibility, AFM may be seen as a new approach to filmmaking. This article has explored what filmmakers need to change (in terms of theory and practice) in order to become accessible filmmakers. From a theoretical point of view, a new mentality or mindset regarding translation may be needed, one that does not deny the difference brought about by translation and accessibility. Just as classic and modern filmmakers such as Federico Fellini, Woody Allen, Stanley Kubrick, Guillermo del Toro or Quentin Tarantino have done, accessible filmmakers are asked to consider the global film and look after its coherence.

As shown in the analysis of Where Memory Ends included in this article, AFM provides these filmmakers with a model to put this into practice, one that is scalable and applicable in different contexts and at different stages, from pre-production to post-production. As far as future avenues of work are concerned, now that there is research showing evidence of the benefits involved in AFM which has been applied in practice, it may be time to start considering the issue of training (Romero-Fresco 2019c), which would need to be provided not only for translators/media accessibility experts but also for filmmakers.

Ultimately, AFM may be seen as a matter of awareness and responsibility. Many filmmakers are simply not aware of the potential impact that translation and accessibility can have on their films. They take for granted that their vision will be preserved across foreign and accessible versions (denial of difference) and end up delegating or abdicating responsibility, thus burdening translators with a task for which they are not properly prepared nor duly remunerated. Taking up the above-mentioned quote by Hitchcock, these filmmakers may be interested in the audience of the original version, but do not seem to bear in mind the global film and the millions of viewers who watch the foreign and 
accessible versions. In contrast, those filmmakers who are or become aware of the impact of translation and access often take responsibility for the different versions and for the overall coherence of the global film, which they can do by implementing the AFM model. These accessible filmmakers are interested in the whole of the audience, so that no-one is left behind.

\section{References}

Aguilar, Carlos. (2019) "Alfonso Cuarón Breaks Down the Use of Language in "Roma," Including Plans for Subtitles in Mixtec." Remezcla. Electronic version: <http://remezcla.com/features/film/alfonso-cuaron-roma-interviewmixtec-subtitles>

AKIN, Fatih. (2007) The Edge of Heaven. Germany, Turkey: The Match Factory.

BARBASH, Ilisa \& Lucien Taylor. (1997) Cross-Cultural Filmmaking A Handbook for Making Documentary and Ethnographic Films and Videos. Los Angeles: University of California Press.

BAUDRY, Jean Louis \& Alan Williams. (1974) "Ideological Effects of the Basic Cinematographic Apparatus.” Film Quarterly 28:2, pp. 39-47.

BERGFELDER, Tim. (2005) "National, transnational or supranational cinema? Rethinking European film studies." Media, Culture and Society 27:3, pp. 315-331.

BILlson, Anne. (2019) "Say what? Why film translators are in a war of words over subtitles." The Guardian. Electronic version: <https://www.theguardian.com/film/2019/apr/25/say-what-why-film-translators-are-in-a-warof-words-over-subtitles>

Boyero, Carlos. (2007) "Estética y fría 'Pozos de ambición'." El País. Electronic version: <https://elpais.com/diario/2008/02/09/cultura/1202511603_850215. html>

BRANSON, Josh. (2019) "Who's DAT? Director of Accessibility and Translation as a (New) Professional Figure in Filmmaking." Presentation at Media for All 8 Conference, Stockholm, 17th - 19th June 2019.

CORTÉS, Rodrigo. (2010) Buried. Spain: Lionsgate.

COSTA, Jordi. (2010) "Para agorafóbicos con criterio." Fotogramas. Madrid. Electronic version: <http://www.fotogramas.es/Peliculas/Buried-Enterrado> CROW, Liz. (2005) "Making Film Accessible" Roaring Girl Productions. Electronic version: <http://www.roaring-girl.com/work/making-film-accessible> 
DANGERFIELD, Kate. (2018) "The value of difference in Media Accessibility Quality." Presentation at Understanding Media Accessibility Quality (UMAQ) Conference, 4-5 June 2018, Barcelona.

Diвв, Mike. (1972) Ways of seeing. United Kingdom: Dibb Productions.

DiвB, Mike. (2001) The Miles Davis Story. United Kingdom: Dibb Productions.

DWYER, Tessa \& Claire Perkins. (2018) "Passing Time: Eye Tracking Slow Cinema, Seeing into Screens Eye Tracking and the Moving Image." In: Dwyer, Tessa; Claire Perkins; Sean Redmond \& Jodi Sita (eds.) 2018. Seeing into Screens. Eye Tracking and the Moving Image. London: Bloomsbury, pp. 103-125.

DWYER, Tessa. (2017) Speaking in subtitles: revaluing screen translation. Edinburgh: Edinburgh University Press.

EGOYAn, Atom \& Ian Balfour. (2004) Subtitles: On the Foreignness of Film. Cambridge: MIT Press.

EISENSCHITZ, Bernard. (2013) "Sous-titrage mon beau souci." Mise au point 5. Electronic version: < https://journals.openedition.org/map/1481>.

Eleftheriotis, Dimitris. (2010) Cinematic Journeys: Film and Movement. Edinburgh: Edinburgh University Press.

FLYNN, Niall. (2016) "An Intimate Encounter: Negotiating Subtitled Cinema." Open Library of Humanities 2, pp. 1-28.

FORD, John. (1953) Mogambo. USA: Sam Zimbalist.

FOzOONI, B. (2006) "All translators are bastards!" South African Journal of Psychology, 36:2, pp. 281-298.

GAGO, Álvaro. (2017) Matria.

GALÁN, Diego. (1981) "Continúan la censura y manipulaciones en el doblaje cinematográfico." El País. Electronic version: <https://elpais.com/ diario/1981/10/11/cultura/371602810_850215.html>

GODARD, Jean-Luc. (1963) Le mépris. France: Les Films Concordia.

GonZÁlEZ IÑÁRRITU, Alejandro. (2006) Babel. United States: Paramount Vantage. Greco, Gian Maria (2016). "On Accessibility as a Human Right, with an Application to Media Accessibility." In: Matamala, Anna \& Orero, Pilar (eds.) 2016. Researching audio description: New approaches. London: Palgrave MacMillan, pp. 11-33.

GreCO, Gian Maria. (2018) "The Case for Accessibility Studies." Journal of Audiovisual Translation, 1:1, pp. 204-232.

HochberG, Julian and Virginia Brooks. (1978) "Film Cutting and Visual Momentum." In: Senders, John W; Dennis F. Fisher \& Richard A. Monty 
(eds.) 1978. Eye Movements and the Higher Psychological Functions. Hillsdale, NJ: Lawrence Erlbaum, pp. 293-317.

JONES, Kent. (2015) Hitchcock/Truffaut. France, USA: Arte France, Artline Films, Cohen Media Group.

JONES, Sam. (2019) "Alfonso Cuarón condemns Spanish subtitles on Roma." The Guardian. Electronic version: <https://www.theguardian.com/film/2019/ jan/09/alfonso-cuaron-condemns-netflix-over-roma-subtitles>

LEV, Peter. (1993) The Euro-American Cinema. The University of Texas Press: The University of Texas Press.

LOBRUTTO, Vincent. (1997) Stanley Kubrick: A biography. New York: Da Capo.

LONGO, Regina. (2017) "A Conversation with Tessa Dwyer on the Risky Business of Subtitling." Film Quarterly. Electronic version: <https://filmquarterly. org/2017/12/04/a-conversation-with-tessa-dwyer-on-the-risky-business-ofspeaking-in-subtitles-revaluing-screen-translation>

MacDougall, David. (1998) "Subtitling Ethnographic Films." Transcultural Cinema. Princeton: New Jersey, pp. 165-178.

Marshall, Alex. (2019) "Mamá to Madre? "Roma" Subtitles in Spain Anger Alfonso Cuarón." The New York Times. Electronic version: <https://www. nytimes.com/2019/01/11/movies/roma-spanish-subtitles-alfonso-cuaron-netflix.html>

McGann, Jerome. (1991) The Textual Condition. Princeton, New Jersey: Princeton University Press.

Monaco, James. (1992) The Movie Guide. New York: Perigee Books.

Morales, Manuel. (2019) "'Roma', una película en español subtitulada en español." El País. Electronic version: <https://elpais.com/cultura/2019/01/08/ actualidad/1546979782_501950.html>

MORRIS, Nigel. (2007) The Cinema of Steven Spielberg: Empire of Light. London: Wallflower Press.

MuRPHY, Heather. (2007) "Oscar noms not lost in translation." Variety. Electronic version: <https:/variety.com/2007/film/awards/oscar-noms-not-lost-intranslation-1117959519/>

NORNES, Abe Mark. (1999) "For an Abusive Subtitling." Film Quarterly 53:3, pp. 17-34.

Nornes, Abe Mark. (2007) Cinema Babel: Translating Global Cinema. Minnesota: University of Minnesota Press. 
Romero-Fresco, Pablo. (2018) "In support of a wide notion of media accessibility: Access to content and access to creation." Journal of Audiovisual Translation 1, pp. 187-204.

Romero-Fresco, Pablo. (2019a) Accessible Filmmaking: Integrating translation and accessibility into the filmmaking process. London: Routledge.

Romero-Fresco, Pablo. (2019b) Donde se acaba la memoria. Spain.

ROMERO-FreSCO, Pablo. (2019c) "Training in Accessible Filmmaking." Linguistica Antverpiensia, New Series: Themes in Translation Studies, 14 (Special issue: Media Accessibility Training).

Romero-Fresco, Pablo \& Louise Fryer (2018) Accessible Filmmaking Guide. London.

SANZ ORTEGA, Elena. (2015) Beyond Monolingualism: a Descriptive and Multimodal Methodology for the Dubbing of Polyglot Films. Unpublished PhD thesis, The University of Edinburgh.

SCORSESE, Martin. (2002) Gangs of New York. USA: Miramax.

SERBAN, Adriana. (2012) "Translation as alchemy: the aesthetics of multilingualism in film." MonTI 4, pp. 39-63.

Shochat, E. and Stam, R. (1985) "The cinema after Babel: Language, difference, power." Screen 26:3-4, pp. 35-58.

SINGER, Erik. (2016) "Movie Accent Expert Breaks Down 32 Actors' Accents". Wired. Electronic version: <https://www.youtube.com/watch?v=NvDvESEXcgE>

SinHA, Amresh. (2004) "The use and abuse of subtitles". In: Egoyan, Atom \& Ian Balfour (eds.) 2004. On the Foreignness of Film. Cambridge, MA: The MIT Press, pp. 172.175.

SPIELBERG, Steven. (2005) Munich. USA: Universal Pictures.

STÖHr, Hannes. (2005) One Day in Europe. Hoerner, Sigrid.

TARANTINO, Quentin. (2009) Inglourious Basterds. United States: The Weinstein Company.

Thomas Anderson, Paul. (2007) There Will Be Blood. USA: Paramount Vantage. THOMAS, François. (2006) Le Film pluriel, Séminaire de recherche, University of

Sorbonne Nouvelle Paris 3. Electronic version: <http://www.univ-paris3.fr/ le-film-pluriel-32626.kjsp>

DEL Toro, Guillermo. (2001) The Devil's Backbone. Spain: Sony Pictures Classics. DEL TORO, Guillermo. (2006) Pan's Labyrinth. Spain: Warner Bros.

TRUFFAUT, François. (1966) Hitchcock. New York: Simon \& Schuster. 
VARELA, Rocío. (2018) Integrated titles: How to convey extra meaning through text design and typographic effects. Unpublished MA dissertation, Universidade de Vigo.

ZANOTTI, Serenella. (2018) "Investigating the genesis of translated films: a view from the Stanley Kubrick Archive" Perspectives. Studies in Translation Theory and Practice 27:2, pp. 201-217.

ZHANG, Jinghing. (2012) "The Interaction between Visual and Written Ethnography in Subtitling." Visual Anthropology 25:1, pp. 439-449.

\section{BIONOTE / BIONOTA}

PABlo ROMERO FRESCO is a Ramón y Cajal researcher at the Universidade de Vigo (Spain) and Honorary Professor of Translation and Filmmaking at the University of Roehampton (London, UK). He is the author of Subtitling through Speech Recognition: Respeaking (Routledge), Accessible Filmmaking (Routledge) and the editor of The Reception of Subtitles for the Deaf and Hard of Hearing in Europe (Peter Lang). He is on the editorial board of the Journal of Audiovisual Translation and is the leader of the international research centre GALMA (Galician Observatory for Media Access), for which he is currently coordinating several international projects on media accessibility, including ILSA: Interlingual Live Subtitling for Access, funded by the EU Commission. Pablo is also a filmmaker. His first documentary, Joining the Dots (2012), was screened during the 69th Venice Film Festival and was used by Netflix as well as film schools around Europe to raise awareness about audiodescription.

PABlo ROMERO FRESCO es investigador Ramón y Cajal en Universidade de Vigo y Honorary Professor of Translation and Filmmaking en University of Roehampton, donde fue profesor titular durante 10 años. Antes de eso, fue profesor titular en Heriot-Watt University durante 5 años. Es autor de las monografías Accessible Filmmaking (Routledge) y Subtitling through Speech Recognition: Respeaking (Routledge) y editor de The Reception of Subtitles for the Deaf and Hard of Hearing in Europe (Peter Lang). Es miembro del comité editorial de Journal of Audiovisual Translation y director del grupo de investigación GALMA (Galician Observatory for Media Access), con el que lidera en la actualidad varios proyectos de investigación sobre accesibilidad a los 
medios (como ILSA, financiado por la Comisión Europea) además de proyectos de transferencia con los gobiernos de Reino Unido, Australia y Canadá y con empresas y cadenas de televisión como Netflix, AMedia, Sky o Subti. Pablo es también director de cine. Su primer documental, Joining the Dots (2012), fue estrenado en el 69 Festival de Cine de Venecia y ha sido usado por Netflix y por escuelas de cine de varios países europeos para aumentar la visibilidad de la audiodescripción. 